\title{
Introduction of actinomycetes starter on coffee fruits fermentation to enhance quality of coffee pulp
}

\author{
Nurleni Kurniawati ${ }^{1}$, Anja Meryandini ${ }^{2}$, Titi Candra Sunarti ${ }^{3 *}$ \\ ${ }^{1}$ Study Program of Biotechnology, Bogor Agricultural University, Bogor, Indonesia, ${ }^{2}$ Department of Agroindustrial Technology, Bogor Agricultural \\ University, Bogor, Indonesia, ${ }^{3}$ Department of Biology, Bogor Agricultural University, Bogor, Indonesia
}

\section{A B S T R A C T}

\begin{abstract}
Coffee pulp contains bioactive compounds such as polyphenols and aldehydes, which are covalently linked to the pulp cell wall. The research aimed to determine of potential Actinomycetes concortia on the degradation of coffee pulp to enhance the yield and quality of coffee pulp polyphenol extracts. In this study, whole coffee fruit were fermented in solid-state cultivation by using concortia of Streptomyces exfoliatus 42 and Streptomyces costaricanus 45I-3 that having cellulolytic and xylanolytic activities. The introduction of Actinomycetes starter accelerated the fermentation which caused the degradation of lignocellulosic components of coffee pulp, and significantly effects on the yield of bioactive compounds such as polyphenols, anthocyanins, tannins, and catechin. Compared to the spontaneous fermentation of coffee fruit, the highest yield of bioactive components extracts produced from $6^{\text {th }}$ day incubation for total polyphenols $\left(1.20 \mathrm{mg} \mathrm{mL}^{-1}\right)$, anthocyanin $\left(109.95 \mathrm{mg} \mathrm{mL}^{-1}\right)$ and the highest yield of catechin $\left(10.38 \mathrm{mg} \mathrm{mL}^{-1}\right)$ produced form $3^{\text {th }}$ day incubation, but introduction of Actinomycetes reduced the tannin contents after fermentation.
\end{abstract}

Keywords: Coffee pulp; Polyphenol; Actinomycetes concortia; Anthocyanin; Tannin

\section{INTRODUCTION}

Indonesia is one of biggest producer and exporter of coffee. Indonesia coffee plantation covers 1.305 .895 ha of land area; and produces 748.109 tonnes of dried coffee bean per year (Ditjenbun, 2012). Coffee fruit cannot be directly consumed; it should be processed by wet, dry, or semi-dry methods (Schewan et al., 2012). Wet method is the most commonly used for coffee processing and it needs a relatively faster method than dry and semi-dry methods. In the wet method, after harvesting process of the coffee fruits, the pulp is mechanically removed and then spontaneously fermented to remove the mucilage layer. This method liberated about $40 \%$ of solid waste from coffee pulp (Saenger et al., 2001). The coffee pulp can be recycled include activities such as composting, feeding to animals, and production of organic fertilizer and biogas (Rojas et al., 2003).

Spontaneous fermentation process carried out by complex microorganisms such as yeast, bacteria, and fungi (Silva et al., 2008). However, spontaneous fermentation of coffee bean can produce variety in quality of coffee products. The bacteria and yeast cultures are usually introduced to make homogenous condition of spontaneous fermentation process. The used of bacterial starter culture in fermentation process could reduce the fermentation time and improve coffee bean quality (Silva et al., 2013). Specific microorganisms were selected for the starter culture during the fermentation process of coffee, since it is important stage to improve the quality of fermentation process and also the sensory quality of coffee liquour (Massawe and Lifa, 2010).

Coffee pulp has a high fiber that consisted of cellulose (49\%), hemicellulose (24.5\%) and (7.63\%) of lignin (Diniyah et al., 2013). Isolates of Actinomycetes (e.g Streptomyces spp.) has been proved can utilize the polysaccharides (e.g. starch, cellulose, hemicelluloses) as nutrients for its metabolism because it can produce extracellular hydrolytic enzymes (Kokulya et al., 2002). Based on Tuncer et al. (2004), the Streptomyces sp. F2621 produces lignin peroxidase, endoglucanase, and xylanase enzymes which can degrade lignocelluloses. Astuti (2011) stated that S. exfoliatus 42 has

\footnotetext{
${ }^{*}$ Corresponding author:

T.C. Sunarti. Department of Agroindustrial Technology, Bogor Agricultural University, Bogor, 16680, Indonesia. Mobile: +6281381055432 ,

E-mail: titi-cs@ipb.ac.id
}

Received: 03 May 2015;

Revised: 14 January 2016;

Accepted: 17 January 2016;

Published Online: 11 February 2016 
endoglucanase and exoglucanase activities, while $S$. exfoliatus 42 also known having xylanolytic activity (Apriyani, 2012); and Nur (2008) reported that S. costaricanus 45I-3 also had xylanolytic activity. In order to obtain the synergistic activity of each strain in this research, the consortium of S. exfoliatus 42 and $S$. costaricanus 45I-3 concortia starter were used to accelerate fermentation process of the whole coffee fruits.

There are many reports of the production of enzyme, antibiotics, organic acids, and bioactive compound which conducted by utilizing agricultural waste as substrates through solid-state fermentation (SSF) (Martins et al.,2013; Murty and Naidu 2011; Prata and Oliviera, 2007; Shankaranand, V.S., and Lonsane, B.K. 2003). However, relatively fewer studies have been conducted on bioactive compound extraction by the action of Actinomycetes through SSF. In the present study, utilization of S. exfoliatus 42 dan S. costaricanus 45I-3 starter consortia in the coffee fruits fermentation to enhance the yield and quality of coffee pulp polyphenol extracts.

\section{MATERIALS AND METHODS}

\section{Microorganisms and cultures preparation}

S. exfoliatus 42 and $S$. costaricanus $45 \mathrm{I}-3$ used in this research were collected from Animal Biotechnology and Biomedical Laboratory, Center for Life Science \& Biotechnology, Bogor Agricultural University. The cultures were re-cultured on a Yeast Starch Agar (YSA) slant which contained: $1.0 \mathrm{~g}$ soluble starch, $0.02 \mathrm{~g} \mathrm{MgSO}_{4} .7 \mathrm{H}_{2} \mathrm{O}, 0.05 \mathrm{~g} \mathrm{~K}_{2} \mathrm{HPO}_{4}, 2.2 \mathrm{~g}$ agar (per $100 \mathrm{~mL}$ ). For $100 \mathrm{~mL}$ of propagation medium, $80 \mathrm{~mL}$ of YSA media were diluted and supplemented by $1 \mathrm{~g}$ of dried coffee pulp powder, then incubated for 7 days at $27^{\circ} \mathrm{C}$.

\section{Preparation of starter culture and fermentation substrates}

The enzyme activity in the coffee pulp media was measured to determine the growth of microbial concortia of Actinomycetes as a starter culture that is used in the next cultivation process. Two cockborers of S. exfoliatus 42 and $S$. costaricanus 45I-3 for each culture were inoculated in propagation medium and incubated at $27^{\circ} \mathrm{C}$ by using a shaking incubator with an agitation speed of $100 \mathrm{rpm}$ for 10 days. The supernatant were collected every day for enzyme activity assay. The starter with highest enzyme activity was used in next cultivation process. Enzyme activity was measured by using DNS (Dinitrosalisilic acid) method by Miller (1959) with glucose to cellulase activity and xylose to xylanase activity as the standard.

Preparation of fermentation substrates were conducted by using whole coffee fruits of Robusta (Coffea canephora) type with uniform quality. Coffee fruits were washed and rinsed by using potable water and then poured into fermentation chamber, contained $500 \mathrm{~g}$ of coffee fruits, and followed by sterilization by using UV light exposures for 60 minutes.

\section{Cultivation process}

In the control treatment (spontaneous fermentation), coffee fruits that have been sterilized further added with $50 \mathrm{~mL}$ of sterile water. In the sample treatment, coffee fruits were added with $50 \mathrm{~mL}$ or $10 \%(\mathrm{v} / \mathrm{w})$ of microbial concortia of Actinomycetes as a starter culture, then incubated for 9 days at $27^{\circ} \mathrm{C}$. Every 3 days the samples was observed, and the samples were conducted on two replicates.

\section{Concortia of actinomycetes cultivation performance}

The influence concortia of Actinomycetes as starter culture addition in SSF to degrade of coffee pulp was characterized by monitoring the changes in the fiber component, reducing sugar and total sugar, and active compounds. After being cultivated, coffee fruits were further peeled to separate their coffee pulp from the coffee beans. Coffee pulp were then dried in an oven at $50^{\circ} \mathrm{C}$ for 48 hours. Coffee pulp that has been dried and then ground to 40 mesh and used for analyses fiber component (Van Soest et al., 1963) and extracted the active compounds. The extraction process was conducted by maceration. A mass $25 \mathrm{~g}$ of coffee pulp powder was extracted by $250 \mathrm{~mL}$ ethanol: water $(80: 20)$ solvent under agitation at $100 \mathrm{rpm}$ for 24 hour in Erlenmeyer flasks. The extract was concentrated using a rotary evaporator. Furthermore, the extract was analyzed for sugars and bioactive compounds.

Analysis of sugars content which obtained such as total sugars were measured by phenol- $\mathrm{H}_{2} \mathrm{SO}_{4}$ method (Dubois et al., 1959), and reducing sugars by DNS method (Miller, 1959). Aliquots (1 mL) and added $2 \mathrm{~mL}$ of DNS reagent. The reaction mixture was incubated for $15 \mathrm{~min}$ at $100{ }^{\circ} \mathrm{C}$ in a water bath. Absorbance was measured at $550 \mathrm{~nm}$ by UV-Vis spectrophotometer.

Analysis bioactive compounds in coffee pulp such total polyphenol content was measured using a modified FolinCiocalteau method (Singleton and Rossi, 1965), and gallic acid was used as a standard, and the $(\% \mathrm{~T})$ by UV-Vis spectrophotometer at a wavelength of $700 \mathrm{~nm}$. The yield $1 \mathrm{gr}$ of extracts were mixed with $5 \mathrm{~mL}$ Folin-Ciocalteau reagent in $100 \mathrm{~mL}$ volumetric flask that contained $50 \mathrm{~mL}$ deionised water. Sodium carbonate solution ( $15 \mathrm{~mL}$ of $20 \%$ $\mathrm{mv}^{-1}$ anhydrous sodium carbonate in deionised water) was added after 1 minute. The volumetric flask were than made up to volume with deionised water and after standing at 2 hour at room temperature the absorbance was measured by UV-Vis spectrophotometer. 
Determination of tannin content with buthanol-HCl method by IAEA (1999) with ethanol-HCl solution (95\%). Solution of ferric (25 ferric ammonium in $2 \mathrm{~N}$ $\mathrm{HCl}$ ) was prepared by mixing $16.6 \mathrm{~mL}$ of $\mathrm{HCl}$ in $100 \mathrm{~mL}$ in deionised water to make $2 \mathrm{~N} \mathrm{HCl}$, and then $2 \mathrm{~g}$ of ferric was dissolved in $\mathrm{HCl}$ solution. Mix to analyze tannins prepared by mixing $0.5 \mathrm{ml}$ of the sample, add $3 \mathrm{~mL}$ of butanol-HCl, was added $0.1 \mathrm{~mL}$ of reagent $\mathrm{Fe}$ into the tube and shaken using a vortex. tubes containing material is heated at $90{ }^{\circ} \mathrm{C}$ for 60 minutes in water bath. Absorbance was measured at $550 \mathrm{~nm}$ by UV-Vis spectrophotometer.

Determine catechins were analyzed by High Performance Liquid Chromatography (HPLC) and anthocyanins measured according to Igelias et al. (2008).

\section{Statistical analysis}

All data were obtained in this research was analysis using statistical analysis. The parameters were observed as fiber compounds (cellulose, hemicellulose, lignin, and extractive compound), sugar (total sugar and reducing sugar), and bioactive compounds (total polyphenol, anthocyanin, catechin, and tannin). The data obtained are shown as the mean \pm standard deviation of 2 replicates and duplo, then analyzed using a Completely Randomized Design (CRD) using SAS software (Statistical Analytic Software version 9.1). Duncan test $\alpha$ : 0.05 to identify significant differences.

\section{RESULTS AND DISCUSSION}

\section{The enzyme activity of actinomycetes concortia starter cultur on coffee pulp medium}

The activity of cellulase and xylanase enzymes by Actinomycetes concortia in coffee pulp medium was measured to determine the time for preparation of Actinomycetes concortia as a starter that was used in the cultivation process (Fig. 1). The concortia enzymes activities were slower produced compared to single Actinomycetes (Data not shown). The increase of enzyme activity was not significant in 1-2 days incubation, since it was that microbial concortia of Actinomycetes in the adaptation phase (lag phase). It is also due to the microbes has not hydrolyze cellulose and xylan as carbon source but using available reducing sugar in coffee pulp. Fontes et al. (2000) reported that the growth of xylanase producing microbes was tested using glucose and xylan as the carbon sources resulted in more rapid cell growth on glucose medium compared with cell growth on xylan medium. The high activity produced from 6 days fermentation, indicating that the growth of Actinomycetes concortia reached the maximum point

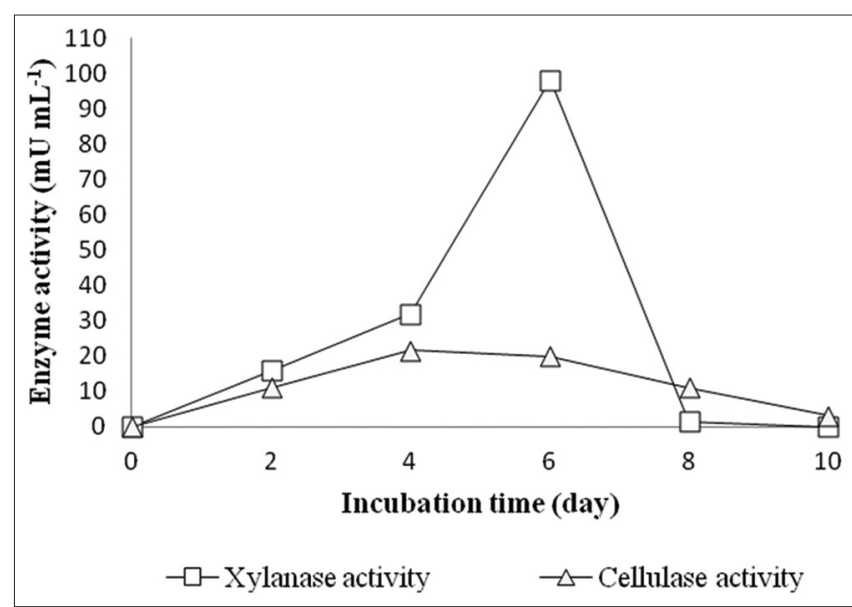

Fig 1. The enzyme activities of Actinomycetes concortia in the coffee pulp medium $1 \%$ and incubated at $27^{\circ} \mathrm{C}$

or exponential phase. The results also showed that Actinomyctes concortia produced higher xylanolytic activity compared to cellulolytic one, even cellulose is the main component of coffee pulp.

Those results are in accordance with the research reported by Tuncer et al. (2004) who stated that the xylanase and cellulase enzymes of Streptomyces sp. FP2621 were produced in the growth phase (exponential). The enzyme activity on Actinomycetes concortia is lower than one isolate of Actinomycetes in CMC and synthetic xylan media. It is due to nutrients competition in utilizing substrate for microbial growth. Interactions between species are not only of synergism or commensalism, but also can be a competition and inhibition (Kato et al., 2005). Differences in enzyme activity is also caused by the presence of polyphenols which can be inhibitors to the enzyme. Polyphenols could bind the enzyme active site thus inhibiting the activity of the cellulase enzyme (McDaugall et al., 2005; Jurgonski et al., 2013). These polyphenols were water-soluble compounds generated due to the reduction of coffee pulp size to 40 mesh as enzyme production medium. Differences in enzyme activity is also due caused by the type and substrate concentration differences. The enzyme has a high specificity to the substrate. The use of different medium causes differences in resulted enzyme activity (White, 1995).

\section{Cultivation performance from actinomycetes concortia} Cultivation of Actinomycetes concortia in the coffee fruits causing the change in fiber contents of coffee pulp. The change was associated with the presence of microbes and their ability to secrete extracellular enzymes. In the control treatment (B), reduction of fiber content was smaller than sample treatment (A) (Table 1). According to Dalzell et al. (1997) decomposition of organic material by microbial and water needed oxygen and nutrients from 
organic matter as a source of energy and then release CO, water and heat energy, causing the weight of the material decreases. A decrease in weight due to the release of $\mathrm{CO}_{2}$ and other compounds. Those results are in accordance with the research reported by Tuomela et al., (2000) organic material of lignocellulosic utilized as a carbon source for microbial metabolic processes that produce energyand release $\mathrm{CO}_{2}$ and the end product is more simple line with produced extracellular enzymes. Weight loss also showed that the consortium actinomycetes able to describe the components used in fiber include cellulose, hemicellulose, and lignin in coffee pulp.

The decrease of fiber content in control (spontaneous fermentation) did not occur significantly, due to the growth of indigenous bacteria on the coffee fruits. According to Silva et al. (2008), naturally, the coffee processing through the spontaneous fermentation involved microorganisms such as Bacillus sp. which was able to hydrolyze cellulose due to its ability to produce cellulase (Coughlan and Mayer, 1991). The role of Actinomycetes starter in the cultivation process was related to its ability to produce extracellular enzymes, such as cellulase, xylanase and lignin peroxidase (Apriyani, 2012). Microbes have the capabilities to produce the enzymes for assimilate organic matter by degrade components of the substrate; more complex substrates is used, more complex enzyme is required to degrade the substrate (Tuomela et al., 2000). Soto et al. (2008) reported the decreasing in cellulose and hemicellulose fibers in Borage officinalis was due to the use of cellulase and xylanase enzymes. The presence of enzyme that was produced by Actinomycetes concortia was effectively used to degrade complex organic components into a simple molecule called monosaccharide which can be used as a carbon source for microbial cells.

The ability of an enzyme to degrade the fiber components depends on the activity of the enzyme possessed. Greater enzyme activity means higher enzyme ability to degrade lignocellulose components. Kammerer et al. (2005) stated that the use of enzyme in the polyphenols extraction from grape processing waste must have the relevant processes such as the type of enzyme, the enzyme-substrate ratio and temperature.
There were differences in the decrease of cellulose, hemicellulose and lignin levels in coffee pulp during fermentation using Actinomycetes concortia. The highest decrease percentage in the lignin and cellulose levels in coffee pulp was on day- 6 at $4.19 \%$ of lignin, $29.11 \%$ of cellulose, and on day-9 at $16.89 \%$ of hemicellulose (Fig. 2). The decrease in lignin content in coffee pulp substrate occured due to lignin peroxidase enzyme activity produced by S. exfoliatus 42. Apriyani (2013) stated that S. exfoliatus 42 was capable of degrading lignin in corn cobs, causing a $4.8 \%$ decrease in lignin content. Peroxidase enzymes could degrade the substrate such as phenols, aromatic amines and several components such as alkyl peroxide (Jing Li et al., 2009). The decrease in lignin content occurred after 3 days of incubation, and the highest decrease in lignin content was occured on $6^{\text {th }}$ day. Tuncer et al. (2004) stated that Streptomyces sp. FP2621 has lignocellulolytic activity as peroxidase. Peroxidase activity increased with cell biomass growth and achieved optimum activity after 4 days of incubation.

The highest decrease in cellulose content occured on day-6. It was linked with the production of cellulase enzyme by S. exfolatus 42 . The result of this degradation is faster than the research conducted by Tuncer et al. (2004). The highest

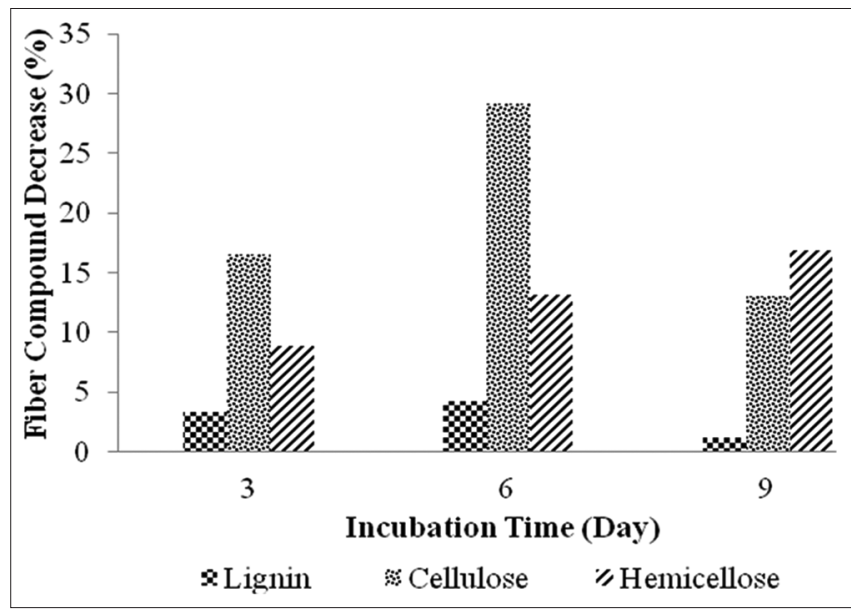

Fig 2. The decrease of lignin, cellulose, and hemicellulose after incubation at $27^{\circ} \mathrm{C}$

Table 1: The composition of the substrate component after cultivation at $27^{\circ} \mathrm{C}$

\begin{tabular}{|c|c|c|c|c|c|}
\hline \multirow{2}{*}{$\begin{array}{l}\text { Fiber compound } \\
(\%)\end{array}$} & \multirow[t]{2}{*}{ Treatment } & \multicolumn{4}{|c|}{ Incubation time (day) } \\
\hline & & 0 & 3 & 6 & 9 \\
\hline \multirow[t]{2}{*}{ Cellulose } & A & $56.30 \pm 0.2^{a}$ & $49.13 \pm 0.6^{b}$ & $30.44 \pm 0.7^{c}$ & $28.65 \pm 0.4^{c}$ \\
\hline & $\mathrm{B}$ & $56.38 \pm 1.2^{d}$ & $51.57 \pm 0.3^{d}$ & $48.33 \pm 0.1^{\mathrm{e}}$ & $45.24 \pm 1.3^{f}$ \\
\hline \multirow[t]{2}{*}{ Hemicellluose } & $A$ & $23.65 \pm 0.3^{a}$ & $18.29 \pm 0.4^{a}$ & $16.00 \pm 0.5^{c}$ & $11.14 \pm 0.3^{d}$ \\
\hline & B & $23.31 \pm 0.2^{\mathrm{a}}$ & $22.92 \pm 0.7^{b}$ & $15.68 \pm 0.7^{c}$ & $10.28 \pm 0.4^{d}$ \\
\hline \multirow[t]{2}{*}{ Lignin } & $A$ & $6.10 \pm 0.1^{a}$ & $3.40 \pm 0.4^{b}$ & $2.90 \pm 0.2^{b}$ & $2.83 \pm 0.1^{b}$ \\
\hline & B & $6.10 \pm 0.1^{a}$ & $5.40 \pm 0.5^{c}$ & $4.90 \pm 0.4^{c}$ & $4.89 \pm 0.5^{c}$ \\
\hline \multirow[t]{2}{*}{ Extractive compound } & A & $13.95 \pm 0.1^{\mathrm{a}}$ & $29.18 \pm 0.2^{b}$ & $50.66 \pm 0.3^{c}$ & $57.38 \pm 0.1^{c}$ \\
\hline & $\mathrm{B}$ & $14.21 \pm 0.1^{d}$ & $20.11 \pm 0.1^{d}$ & $30.09 \pm 0.3^{e}$ & $36.59 \pm 0.1^{f}$ \\
\hline
\end{tabular}

Data: Mean \pm standard deviation; $\alpha=0.05$, Note: A: Sample (Actinomycetes consortium), B: Control (Spontaneous fermented) 
hydrolysis of straw substrate with endoglucanase produced by Streptomyces sp. FP2621 was on $7^{\text {th }}$ day (Tuncer et al., 2004). Jager et al. (2010) stated that the microbes could hydrolyze crystalline cellulose through cellulase enzymes depends on the crystallinity of cellulose. Cellulase enzyme could hydrolyze cellulose in plant cell walls. This hydrolyze process caused insoluble fiber content decrease into more soluble and simple components (Yoon et al., 2005). Wang et al. (2008) describe that the cellulase enzymes produced by microbes to utilize cellulose involve the combined hydrolysis enzymes, consisting of endoglucanase, exoglucanase (cellobiohydrolase), and $\beta$-glucosidase.

The highest decrease in hemicellulose content in $9^{\text {th }}$ day of incubation was related to xylan hydrolyzation by xylanase enzyme, because xylan is the largest component of hemicellulose. The xylanolytic enzyme system that carries out the xylan hydrolysis is normally composed of a repertoire of hydrolytic enzymes, including endo1.4- $\beta$ xylanase that cleaving the glycosidic bonds and in liberating short xylooligosaccharides, $1.4 \beta$-D $\mathrm{D}$-xylosidase to convert xylooligosaccharide into xylose. The side constituent groups of xylan will be released by $\alpha$-L-arabinofuranosidase, $\alpha$-Dglucuronidase, and acetyl xylan esterase to arabinose, glucuronic acid, and acetate (Subraminayan and Prema, 2002). The hydrolysis mechanism of xylan is initiated by $\alpha$-arabinofuranosidase that capable of hydrolyze xylan into L-arabinose and xylobiose. The cleavage of branch chain of xylan will facilitate the hydrolysis of xylanase by exoxylan and $\beta$-xylosidase. The main products of hydrolysis of these enzymes were xylose, arabinose, xylotetrose, and xylotriose (Puspaningsih, 2004).

Lignocellulose hydrolysis by lignocellulolytic enzymes also affects to the yield of the extracts such as total sugar, reducing sugar, and bioactive compounds. The determination of components is done by extracting using a polar solvent is ethanol. Therefore, in this study the measured components of the extraction of the bioactive components that are polar. Polyphenols are a group of polar compounds which contains an $\mathrm{OH}$ group (Shi et al. 2003). Measurement of the sugar component is the total sugar and reducing sugar, whereas the bioactive compounds include total polyphenols, anthocyanins, tannins and catechins. The result of the extraction coffee pulp showed that the total sugar content was increasing after treated by Actinomycetes concortia compared to the spontaneous cultivation. The analysis result showed that the use of Actinomycetes concortia affected the yield of sugar content and Duncan's test also showed significant differences between control and sample treatment (Table 2).

The highest of total sugar content from the cultivation process using starter culture of Actinomycetes concortia occoured on $3^{\text {th }}$ day of incubation, but a few decreased on $6^{\text {th }}$ day of incubation. It is because on $6^{\text {th }}$ day, Actinomycetes concortia only converted oligosaccharides into monosaccharides. The yield of reducing sugar in control was a few increased or constant, in contrast to the sample treatment. It is due to microbes that are present during the fermentation process. In the sample treatment, reducing sugar increased on $3^{\text {th }}$ day of incubation and reached the highest on $6^{\text {th }}$ day of incubation. It is in accordance with the highest degradation of complex fiber component (Fig. 2). Reducing sugar is a product of cellulose and xylan degradation by enzyme generated microbes. Degradations of xylan and cellulose produce monomeric sugars in the form of reducing sugar. According to Saha (2004), hydrolysis of cellulose produces glucose monomers and cellobiose oligomers, while xylan produces xylose, arabinose, and xylooligosaccharide. According to Yoon et al., (2005) fiber hydrolysis using cellulase enzymes obtained some sugar components are monosaccharides (glucose, fructose, galactose, and arabinose), cellooligosaccharides (cellopentaose, cellotetraose, cellotriose, and cellobiose), and galactooligosaccharides (galactotetraose and galactotriose).

The degradation of lignocellulose component would affect the extraction yield of bioactive compounds in coffee pulp. The result of total polyphenols extract obtained was higher in the process using starter culture of Actinomycetes concortia compared with the spontaneos cultivation (Table 3 ). The statistical analysis using $\alpha$ : 0.05 also showed that the use of Actinomycetes concortia was significant impact on the yield of bioactive compounds extract and Duncan's test also showed significant differences between control and sample treatment. In the control, there were limited number of microorganisms during fermentation that caused slightly increased in polyphenol extracts obtained. In fermentation, the presence of hydrolytic enzymes not only causes the degradation of the cell wall, but also might affect phenolic compounds stability. Hydrolysis using an enzyme decreases the viscosity of the substrate, reduce the attractive forces between molecules and decrease the stability of the interaction between uronic acids, proteins, and tannins. In contrast, the breaking of a cell wall polymer increases permeability and porosity of the cell, enchance solubility of internal cell components with a consequent increase in the concentration of phenolic compounds and the antioxidant activity of the extract (Cerda et al., 2013). Therefore, the addition of Actinomycetes concortia culture can improve the yield of bioactive compounds particularly polyphenol compound extracts. The yield analysis of secondary metabolites include four of bioactive compounds of coffee pulp, such as total polyphenols, tannins, anthocyanins, and catechins. Ramirez-Coronel et al. (2004) 
Table 2: Yield sugar was extracted after cultivation at $27^{\circ} \mathrm{C}$

\begin{tabular}{|c|c|c|c|c|c|}
\hline \multirow[t]{2}{*}{ Compound } & \multirow[t]{2}{*}{ Treatment } & \multicolumn{4}{|c|}{ Incubation time (day) } \\
\hline & & 0 & 3 & 6 & 9 \\
\hline \multirow[t]{2}{*}{ Total sugar $\left(\mathrm{mg} \mathrm{mL}^{-1}\right)$} & A & $11.94 \pm 0.62^{c}$ & $19.60 \pm 1,62^{\mathrm{a}}$ & $16.25 \pm 0.85^{b}$ & $10.82 \pm 0.87^{c}$ \\
\hline & B & $12.17 \pm 1.31^{c}$ & $11.98 \pm 1.31^{c}$ & $11.89 \pm 1.30^{c}$ & $12.35 \pm 0.00^{c}$ \\
\hline \multirow[t]{2}{*}{ Reducing sugar (mg mL $\mathrm{mL}^{-1}$ ) } & A & $2.06 \pm 0.00^{b}$ & $4.82 \pm 0.01^{\mathrm{a}}$ & $4.86 \pm 0.01^{\mathrm{a}}$ & $1.73 \pm 1.01^{\mathrm{c}}$ \\
\hline & $B$ & $2.06 \pm 0.16^{b}$ & $2.53 \pm 0.18^{b}$ & $2.78 \pm 0.18^{b}$ & $2.67 \pm 0.19^{b}$ \\
\hline
\end{tabular}

Data: Mean \pm standard deviation; $\alpha=0.05$, Note: A: Sample (Actinomyset concorcia), B: Control (Spontaneous fermented)

Table 3: The yield of the bioactive compounds after cultivation at $27^{\circ} \mathrm{C}$

\begin{tabular}{|c|c|c|c|c|c|}
\hline \multirow[t]{2}{*}{ Compound } & \multirow[t]{2}{*}{ Treatment } & \multicolumn{4}{|c|}{ Incubation time (day) } \\
\hline & & 0 & 3 & 6 & 9 \\
\hline \multirow[t]{2}{*}{ Polyphenol (mg mL $\left.{ }^{-1}\right)$} & A & $0.75 \pm 0.01^{d}$ & $0.76 \pm 0.00^{d}$ & $1.20 \pm 0.00^{\mathrm{a}}$ & $1.15 \pm 0.04^{b}$ \\
\hline & $\mathrm{B}$ & $0.75 \pm 0.03^{d}$ & $0.75 \pm 0.03^{d}$ & $0.86 \pm 0.02^{c}$ & $0.87 \pm 0.02^{c}$ \\
\hline \multirow[t]{2}{*}{ Tannin (\%) } & A & $2.49 \pm 0.15^{d}$ & $2.77 \pm 0.17^{c}$ & $4.20 \pm 0.14^{a}$ & $2.94 \pm 0.00^{\circ}$ \\
\hline & B & $2.28 \pm 0.12^{\mathrm{d}}$ & $2.70 \pm 0.12^{\mathrm{c}}$ & $4.34 \pm 0.08^{a}$ & $3.97 \pm 0.02^{b}$ \\
\hline \multirow[t]{2}{*}{ Anthocyanin (mg g ${ }^{-1}$ ) } & A & $57.68 \pm 0.23^{d}$ & $58.00 \pm 0.2^{c}$ & $109.95 \pm 0.1^{a}$ & $68.00 \pm 0.1^{c}$ \\
\hline & B & $57.68 \pm 0.2^{\mathrm{d}}$ & $59.32 \pm 0.2^{c}$ & $101.59 \pm 0.1^{\mathrm{a}}$ & $66.36 \pm 0.1^{b}$ \\
\hline \multirow[t]{2}{*}{ Catechin $\left(\mathrm{mg} \mathrm{mL}^{-1}\right)$} & A & 0.24 & 10.38 & 0.79 & 0.34 \\
\hline & B & 0.24 & 6.99 & 0.61 & 0.32 \\
\hline
\end{tabular}

Data: Mean \pm standard deviation; $\alpha=0.05$, Note: A: Sample (Actinomyset concorcia), B: Control (Spontaneous fermented)

found the bioactive compounds consisted of four main classes of polyphenols in coffee pulp, i.e. flavan-3-ols, hydroxycinnamic acids, flavonols, and anthocyanidins.

The yield of extraction showed that the highest total polyphenol was obtained on $6^{\text {th }}$ day of incubation. According to Huang et al. (2007), a mixture of Aspergillus oryzae and Trichoderma reesei that produces cellulase and xylanase enzymes can improve the yield of ellagic acid extract which is classified as polyphenols. Laroze et al. (2010) and Collao et al. (2007) also reported that the use of commercial enzyme mixture such as cellulase and hemicellulase can enhance the yield of polyphenol extracts that can be used as antioxidant from Raspberry and Oenothera biennis. Maier et al. (2008) also stated that the use of a mixture of two types of commercial enzymes can improve the yield of polyphenol extracts in grapes. Extraction of phenolic antioxidants from vegetables using enzymes may occur through hydrolytic degradation of polysaccharides in cell wall. These phenolics are bound to lignin and polysaccharides by hydrogen or hydrophobic bonds. In addition, other mechanisms may also be carried out by enzymes which are directly cleave the ether or ester bonds between the phenols and plant cell wall polymers (Pinelo et al., 2008). Increase of total polyphenolic compounds also occurs due to the release of the bond between the components of cellulose, hemicellulose and lignin with polyphenolic compounds. Polyphenolic compounds are covalently bound to the cell wall. According to Gonzales et al. (2011), solid fermentation using Aspergillus tamarii was able to improve the yield of phenolic compound extracts in the form of hydroxycinnamic acid from the coffee pulp that can be used as an antioxidant compound. Tannin extract obtained in the sampel treatment was lower compared with the control treatment (Table 3). The same study results that use Streptomyces sp. through solid state fermentation showed the decrease in polyphenols content in coffee pulp (Orozco et al., 2008). The different results shown by Moreno-Peres et al. (2010), in which tannin extract from grapes increased after fermented using pectinase and $\beta$-galactosidase enzymes. The reduction of polyphenols content, particularly tannin from fermented coffee pulp, can be utilized as animal feed. It caused by tannins can inhibit the growth of fiber-degrading bacteria in the digestive tract of ruminants (Ozkose et al., 2011). Increased tannin extract in both control and sample treatments was followed by an increase in its monomer called catechin. The yield of catechins increased dramatically after 3 days of incubation.

The increase of total polyphenols was apparently due to increase one of its components, such as anthocyanin. In the sample treatment, the yield of anthocyanin extract was higher than control. Polyphenolic compounds such as anthocyanins have covalent bonds to the cell wall. Those results are in accordance with the research reported by Ramirez-coronel et al., (2004) who stated that the increased of anthocyanin extracts yield was occurred after 3 days of incubation. According to Jurgonski et al. (2013), $\beta$-glucosidase enzyme can increase anthocyanin extracts from L. caerulea. Extraction of polyphenol and anthocyanin from Blackcurrent fruits can improved the yields by cellulase and hemicellulase enzymes derived from Trichoderma spp. (Kapasakalidis et al., 2009). Prata and Oliveira (2007) described the use of fresh coffee pulp as a potential source of natural dye due to the content of 
cyanidin-3-rutinoside anthocyanin. Murthy et al. (2012) also reported that the red color of coffee pulp contained cyanidin-3-rutinoside and cyanidin-3-glucoside that potential as antioxidants and natural dye foods. In addition, Pinelo et al. (2008) stated that $\beta$-galactosidase enzyme from Aspergillus niger and cellulase enzyme from Trichoderma reesei were able to improve the yield of polyphenol components. The measured polyphenol content increased due to an increase in the chlorogenic acid content.

\section{CONCLUSION}

The utilization of actinomycetes concortia in solid-stated fermentation has a mixture of cellulase, xylanase, and peroxidase activities which can degrade lignocellulose components of coffee pulp. Degradation of lignocellulosic components can improve the yield and quality of polyphenols extraction. The highest production of polyphenols and anthocynins extract was produced on $6^{\text {th }}$ day incubation for total polyphenols $\left(1.20 \mathrm{mg} \mathrm{mL}^{-1}\right)$, anthocyanin $\left(109.95 \mathrm{mg} \mathrm{mL}^{-1}\right)$ and the highest yield of catechin $\left(10.38 \mathrm{mg} \mathrm{mL}^{-1}\right)$ produced form $3^{\text {th }}$ day incubation. However, the results were lower than tannin extract. Coffe pulp contained low tannin can be used as animal feed.

\section{ACKNOWLEDGEMENTS}

This publication is part of the research funded by Indonesian Ministry of Research \& Technology, and Higher Education National Strategic Research Grant to Titi Candra Sunarti through Institute of Research and Community Empowerment, Bogor Agricultural University.

\section{Author contributions}

$\mathrm{N}$. K., designed the study, did the analysis, and wrote the article, T. C. S., and A. M., designed the study, corrected the artikel.

\section{REFERENCES}

Apriani, I. 2013. Selection of actinomycetes for degradation lignocellulosic biomass. Thesis. Bogor Agricultural University, Indonesia.

Astuty, E. 2012. Activity of cellulolytic and characterization actinomycetes from peat soils. Thesis. Bogor Agricultural University, Indonesia.

Brand, D., A. Pandey, J. A. Rodríguez-Leon, S. Roussos, I. Brand and C. R. Soccol. 2001. Packed bed column fermenter and kinetic modeling for upgrading the nutritional quality of coffee husk in solid-state fermentation. Biotechnol. Prog. 17: 1065-1070.

Beg, Q. K., M. Kapoor, L. Mahajan and G. S. Hoondal. 2001. Microbial xylanases and their industrial application: A review. Appl. Microbiol. Biotechnol. 56: 326-338.

Collao, C. A., E. Curotto and M. E. Zuniga. 2007. Enzymatic treatment on oil extraction and antioxidant recuperation from Oenothera biennis by cold pressing. Grasas y Aceites. 58: 10-14.

Coughlan, M. P. and F. Mayer. 1991. The cellulose-decomposing bacteria and their enzymes systems. Prokaryotes. 1: 460-516.

Dalzel, H. W., A. J. Biddlestone, K. R. Gray and K. Thurairajan. 1997. Soil management: compost production and use in tropical and sub tropical environments. Soil Bull. 56: 175-177.

Directorate General of Plantation. 2012. The Area and Coffee Production in Indonesian. Directorate General of Plantation. Ministry of Agriculture RI, Indonesia.

Diniyah, N., N. Maryanto, S. Ahmad, S. Demi and S. Achmad. 2013. Extraction and characterization of the water soluble polysaccharides from coffee pulp of Arabica (Coffea arabica) and Robusta (Coffea canephora) Variety. Agric. Technol. 14: 73-78.

Dubois, M. 1959. Colorimetric method for determination of sugar and related substances. Anal. Chem. 28: 360-356.

Fontes, C. M. 2000. A novel cell Vibrio mixtus family 10 xylanase that is both intracellular and expressed under non-inducing conditions. J. Microbiol. 145: 1959-1967.

El-Sersy, N. A., H. Abd-Elnaby, G. M. Abou-Elela, H. A. Ibrahim and N. M. K. El-Toukhy. 2010. Optimization, economization and characterization of cellulase produced by marine Streptomyces ruber. Afr. J. Biotechnol. 9: 6355-6364.

Gonzalez, M., A. R. Coronel and M. Mancera. 2011. Antioxidant activity of fermented and nonfermented coffee (Coffea arabica) pulp extracts. J. Food Technol. Biotechnol. 49: 374-378.

Guyot, S., N. Marnet, P. Sanoner and J. F. Drilleau. 2001. Direct thiolysis on crude apple materials for high-performance liquid chromatography. Characterization and quantification of polyphenols in cider apple tissues and juices. Methods Enzymol. 335: $5770-5776$.

IAEA. 1999. Working Document. Quantification Taninns in Tree Foliage. Join FAO/IAEA Division of Nuclear Techniques in Food and Agricultural Animal Production and Health Sub Program. IAEA Working Document IAEA, Viena.

Iglesias, I., G. Echeverria and Y. Soria. 2008. Differences in fruit colour development, anthocyanin content, fruit quality, and consumer acceptability of eight "Gala" apple starins. Sci. Hortic. 7: 3014-3022.

Kammerer, D., A. Claus, A. Schieber and R. Carle. 2005. A novel process for the recovery of polyphenols from grape (Vitis vinifera L.) pomace. Food Sci. 70( 2):157-163.

Kapasakalidis, P. G, R. A. Rastall, and M. H. Gordon. 2009. Effect of a cellulase teatment on extraction of antioxidant phenols from black currant (Ribes nigrum L.) pomace. Agric. Food Chem. 57(10): 4342-4351.

Kato, S., S. Haruta, Z. J. Cui, M. Ishii and Y. Igarashi. 2005. Srable coexistence of five bacterial strains as a celullose-degrading community. Appl. Environ. Microbiol. 71: 7099-7106.

Kukolya, J., I. Nagy, M. Laday, E. Toth, O. Oravecz, K. Marialigeti and L. Hornok. 2002. Thermobifida cellulolytica sp. nov., a novel lignocellulose decomposing actinomycete. Int. J. Syst. Evol. Microbiol. 52: 1193-1199.

Laroze, L., C. Soto and M. E. Zuniga. 2010. Antioxidants extraction from raspberry wastes assisted byenzymes. Electron. J. Biotechnol.13: 6-17.

Madigan, M. T., J. M. Martinko and J. Parker. 2006. Biology of Microorganism. Prentice Hall, New Jersey.

Maki, M. L., K. T. Leung and W. Qin. 2009. The prospects of cellulase producing bacteria for the bioconversion of lignocellulosic biomass. Int. J. Biol. Sci. 5: 500-516.

Martins, S., J. A. Teixeira and S. I. Mussatto. 2013. Solid-state 
fermentation as a strategy to improve the bioactive compounds recovery from Larrea tridentata leaves. Appl. Biochem. Biotechnol. 171(5): 1227-39.

Massawe, G. A. and S. J. Lifa. 2010. Yeasts and lactic acid bacteria coffee fermentation starter cultures. Post. Technol. Innov. 2: 41-80.

Miller, G. L. 1959. Dinitrosalicylic acid reagent for determination of reducing sugar. Anal Chem. 31: 426-428.

Moreno-peres, A., J. I. Fernandez-fernandez, A. Martinez-cutillas, R. Vila-lopez and R. Gilmunoz. 2010. Effect of selected enzymes over chromatic parameters during maceration periodin syrah and cabernet-sauvignon. J. Int. Sci. Vigne Vin. 15: 41-50.

Murty, P. S. and M. M. Naidu. 2011. Improvement of robusta coffee fermentation with microbial enzymes. Eur. J. Biol. Sci. 3: $130-139$

Murthy, P. S., M. R. Manjunatha, G. Sulochannama, and M. N. Madhava. 2012. Extraction, characterization and bioactivity of coffee anthocyanins. Eur. J. Biol. Sci. 4: 13-19.

Nur, H. S., A. Meryandini and Hamim. 2008. Utilization of cellulolytic and xilanolitik bacteria potential for decomposition of rice straw. J. Trop. Land. 14: 71-80.

Orozco, A. L., M. I. Perez, O. Guevara, J. Rodriguez, M. Hernandez and F. J. Gonzalez-Vila. 2008. Biotechnologic al enhancement of coffee pulp residues by solid-state fermentation with Streptomyces. Py-GC/MS analysis. J. Anal. Appl. Pyrolysis. 81: 247-252.

Pinelo, M., B. Zornoza and A. S. Meyer. 2008. Selective release of phenols from apple skin: Mass transferkinetics during solvent and enzyme-assisted extraction. Sep. Purif. Technol. 63: 620-627.

Prata, E. R. B. and L. S. Oliveira. 2006. Coffee husk and potential sources of anthocyanins. Appl. Clay. Sci. 40: 1555-1660.

Ramirez-Coronel, M. A., N. Marnet, V. S. K. Kolli, S. Roussos, S. Guyot and C. Augur. 2004. Characterization and estimation of proanthocyanidins and other phenolics in coffee pulp (Coffea arabica) by Thiolysis-high performance liquid chromatography. Agric. Food Chem. 52: 1344-1349.

Rojas,J. B. U., J. A. J. Verte., S. Amato and E. A. Hisman. 2003. Biological treatments affect the chemical composition of coffee pulp. Bioresour. Technol. 89: 267.

Saenger, M., E. U. Hartge, J. Werther, T. Ogada and Z. Siagi, 2001.
Combustion of coffee husks. Renewable Energy. 23: 103-121.

Saha, B. C. 2003. Hemicellulose bioconversion. J. Ind. Microbiol. Biotechnol. 30: 279-291.

Shankaranand, V. S. and B. K. Lonsane. 2003. Coffee husk: an inexpensive substrate for production of citric acid by Aspergiilus niger in a solid-state fermentation system. J. Microbiol. Biotechnol. 10: 165-168.

Shi J, Y. J., J. Pohorly, J. C. Young, M. Bryan and Y. Wu. 2003. Optimization of the extraction of polyphenols from grape seed meal by aqueous ethanol solution. J. Food Agric. Environ. 1: $42-47$.

Singleton, V. L. and J. A. Rossi. 1965. Colorimetry of total phenolic with phosphomolybdic-phosphotungstic acid reagent. Am. J. Enol. Vitic. 16: 147.

Soto, C., R. Chamy and M. E. Zuniga. 2007. Enzymatic hydrolysis and pressing conditions effect on borage oil extraction by cold pressing. Food Chem. 102: 834-840.

Subraminayan, S. and P. Prema. 2002. Biotechnology of microbial xylanase: Enzymology, molecular biology, and application. Crit. Rev. Biotechnol. 22: 3364-3369.

Tuomela, M., M. Vikman, A. Hatakka and M. Itavaara. 2000. Biodegradation of lignin in a compost environment: A review. Bioresour. Technol. 72: 169-183.

Tuncer, M., A. Kuru, M. Isikli, N. Sahin and F. G. C. Elenk. 2004. Optimization of extracellular endoxylanase, endoglucanase and peroxidase production by Streptomyces sp. F2621 isolated in Turkey. Appl. Microbiol. 97: 783-791.

Van Soest, P. J., J. B. Robertson and B. A. Lewis. 1991. Methods For Dietary Fiber, neutral detergent fiber, and nonstach polysaccarides in relation in animal nutrition. J. Dairy Sci. 74: 3583-3597.

Yee, D. C. and T. K. Jahng. 1996. Enhanced expression and hidrogen peroxide depence of ligninperoxide from Streptomyces viridosporus T7A. Biotechnol. Prog. 12: 40-46.

Yoon, K. Y., M. Cha, S. R. Shin and K. S. Kim. 2005. Enzymatic production of a soluble-fibre hydrolyzate from carrot pomace and its sugar composition. Food Chem. 92: 151-157.

Wang, C. M., C. L. Shyu, S. P. Ho and S. H. Chiou. 2008. Characterization of a novel thermophilic, cellulose degrading bacterium Paenibacillus sp. strain B39. Lettr. Appl. Microbiol. 47: 46-53. 